\title{
Nilai-nilai Dakwah Dalam Yayasan Perguruan Bela Diri Muda Berakhlak di Kabupaten Lebong
}

\author{
Andiansyah \\ IAIN Curup \\ Email:Andy.ansyah20@gmail.com
}

\begin{abstract}
Achieving maximum effectiveness of da'wah, a cadre is required to understand the values of da'wah and be able to implement them properly and accurately so that they are in accordance with the conditions of the missionary object. At present, the problems that arise are increasingly developing, so the effort to carry out da'wah is also getting harder. To overcome the problems of da'wah in the present and in the future, it is necessary to prepare qualified future cadres. The formation of successor cadres which is one of the aims of establishing the Foundation, where the Endless Youth Foundation seeks cadres as a strategy in the effort to develop its vision and misidakwah program. The aim of this research is to find out how the values of da'wah developed and applied in the foundation have. This research is a field research that uses a descriptive qualitative method, the informants in this research are the leaders of the Youthless Foundation, the supervisor of the Youthful Foundation, the daily administrators of the Youthful Youth Self Defense College, the Skilled Young Self-Defense Professor, and cadres and members of the College Youthful Martial Arts. data sources namely secondary data and primary data. Techniques for collecting data using observation, interviews and documentation. The analysis technique uses deductive and inductive. In processing the data the researcher collects data, is classified according to the subsequent needs analyzed. Based on the results of the program research in the Young Self Defense College Foundation with the following characteristics: Self-defense as a place to develop talent, Indonesian culture and treatment according to Islamic law (Ruqiab). Da'wah activities of the Young Martial Arts Foundation Foundation have the following characteristics: qiker, praying before and after training, memorizing alqurans and hadiths every time the test increases the level of the belt in cadre, as well as the motivation of preaching and being guided. The values of da'wah developed and applied in the Youthful Youth Self Defense Foundation include: the value of discipline, honesty, hard work, cleanliness, competition, solidarity, monotheism, patience, sincerity, istiqomah, and morals. Supporting factors in the Youthful Youth Self Defense Foundation are the community and local government, and the inbibiting factor is the difficulty in finding teachers, coaches, funds, location, and infrastructure.
\end{abstract}

Keywords: Young, martial, arts college, with character 
58 |Jurnal Dakwah dan Komunikasi, Vol. 4 , No. 1 , 2019

\begin{abstract}
Abstrak
Mencapai tingkat efektivitas dakwah yang maksimal, seorang kader dituntut untuk memahami nilai-nilai dakwah dan mampu mengimplementasikannya dengan baik dan akurat sehingga sesuai dengan kondisi objek dakwahnya. Diera sekarang problema yang timbul semakin berkembang dengan demikian upaya penyelenggaraan dakwah juga semakin berat. Untuk mengatasi problematika dakwah di masa kini dan akan datang perlu disiapkan kader-kader penerus yang berkualitas. Pembentukan kader penerus yang merupakan salah satu tujuan didirikannya Yayasan, dimana Yayasan Muda Berakhlak mengupayakan kader sebagai strategi dalam upaya pengembangan program visi dan misidakwahnya. Tujuannya dalam penelitian ini untuk mengetahui bagaimana nilai-nilai dakwah yang dikembangkan dan diterapkan dalam yayasan perguruan bela diri muda berakhlak tersebut. Peneletian ini merupakan peneletian lapangan (field research) yang menggunakan metode deskriptif kualiatatif, informan dalam peneletian ini adalah pimpinan Yayasan Muda Berakhlak, pengawas Yayasan Muda Berakhlak,pengurus harian Perguruan Bela Diri Muda Berakhlak, Guru Besar Bela Diri Muda Berakhlak, serta kader dan anggota Perguruan Bela Diri Muda Berakhlak. sumber data yaitu data sekunder dan data primer. Tekhnik pengumpulan data menggunakan observasi, wawancara serta dokumentasi. Tekhnik analisa menggunkan deduktif dan induktif. Dalam pengolahan data peneliti mengumpulkan data, diklafikasikan sesuai kebutuhan selanjut dianalisa. Berdasarkan hasil penelitian program dalam Yayasan Perguruan Bela Diri Muda Berakhlak antara lain: Bela diri sebagai wadah mengembangkan bakat, budaya Indonesia dan pengobatan sesuai syariat Islam (Ruqiah). Aktivitas dakwah Yayasan Perguruan Bela Diri Muda Berakhlak diantaranya: berzikir, berdoa sebelum dan sesudah latihan, hapalan alqur'an dan hadits setiap ujian kenaikan tingkat sabuk dalam pengkaderan, serta motivasi dakwah dan binaan. Nilai-nilai dakwah yang dikembangkan dan diterapkan dalam Yayasan Perguruan Bela Diri Muda Berakhlak tersebut antara lain: nilai kedisiplinan, nilai kejujuran, nilai kerja keras, nilai kebersihan, nilai kompetisi, nilai solidaritas, nilai tauhid, nilai kesabaran, nilai keikhlasan, nilai istiqomah, dan akhlak. Faktor pendukung dalam Yayasan Perguruan Bela Diri Muda Berakhlak yaitu masyarakat dan pemerintah daerah, serta faktor penghambat yaitu kesulitan dalam mencari guru, pelatih, dana, lokasi, dan sarana prasarana.
\end{abstract}

Kata Kunci: Perguruan, bela diri, muda, berakhlak 


\section{Pendahuluan}

\section{Latar Belakang}

Dengan berbagai macam perubahan sosial mestinya agama (dakwah) tampil untuk membantu manusia memahamkan kejadian baru yang sering sukar dijangkau oleh akal manusia. Karena ketika kemajuan dramatis iptek tidak lagi sepenuhnya sanggup menjawab masalah-masalah sosial, budaya dan ekonomi yang ditimbulkannya, maka mau tidak mau orang akan mencari pemecahan melalui pendekatan agama. Dalam melaksanakan proses pelembagaan nilai-nilai dakwah, titik berangkatnya berasal dari pemahaman tentang konsepsi dakwah menurut ajaran Islam. Konsepsi dakwah inilah yang menjadi landasan ontologis untuk diturunkan dalam tataran praksis di organisasi dakwah atau di masyarakat. Mengingat dakwah adalah upaya "menurunkan" dan menjadikan nilai-nilai Al-Qur'an agar membudaya dalam kehidupan masyarakat. ${ }^{1}$

Nilai-nilai yang telah menginternal dalam diri para pelaku dakwah akan terus dibawa dan dikembangkan melalui interaksi sosial yang terjadi di organisasi dakwah dan terbentuk menjadi nilai-nilai dakwah.Nilai-nilai dakwah tersebut akan terus-menerus dipraktikkan oleh para pelaku dakwah menjadi kebiasaan dan tata aturan yang pada akhirnya melahirkan institusi. ${ }^{2}$ Oleh karena itu, kesiapan pelaku dakwah dalam berbagai hal seperti yang telah dijelaskan di atas untuk menjawab serta mengantisipasi tantangan adalah sebuah keharusan bagi para pelaku dakwah sehingga ketika terjadi kemungkinankemungkinan yang tidak diprediksi sebelumnya dapat diatasi, bahkan dijadikan sebagai peluang keberhasilan dakwah. Karena hal itulah perlu adanya nilai-nilai dakwah yang dikembangkan dan diterapkan dalam sebuah Yayasan Perguruan Bela Diri Muda Berakhlak dalam hal pelaksanaan dakwah tersebut agar dakwah yang dilakukan sesuai dengan visi dan misi yang hendak dicapai.

Dengan adanya organisasi keIslaman yang mengemban nilai-nilai dakwah tentunya diharapkan bisa mendidik dan melaksanakan misinya sesuai dengan ajaran Islam yang rahmatan lil'alamin. Organisasi keIslaman bukan hanya saja sebagai tempat berkumpul tetapi sebagai wadah dan media untuk menyampaikan nilai-nilai keIslaman terhadap anak-anak dan remaja khususnya kader dan anggota dalam Yayasan Perguruan Bela Diri Muda Berakhlak Kabupaten Lebong. Tugas berat umat Islam adalah bagaimana merubah ajaran Islam menjadi ajaran yang dapat menginspirasi dan mendorong manusia untuk memiliki kesadaran tinggi dalam mempraktekkan ajaran Islam. Sebenarnya, setiap ajaran Islam yang kita pelajari sudah mengandung nilai-nilai bagi kehidupan manusia. Hanya saja terjadi kesenjangan antara teori yang diajarkan dengan praktek yang dilakukan.

Nilai-nilai dakwah terdapat pada suatu kegiatan, salah satunya dalam Yayasan Perguruan Bela Diri Muda Berakhlak di Kabupaten Lebong yakni menanamkan nilainilai keIslaman yang bersumber dari Alqur'an dan Hadits Rasulullah SAW. Nilai-nilai dakwah yang diterapkan dan ditanamkan diantaranya, nilai tauhid, nilai kesabaran, nilai

${ }^{1}$ Muhammad Sulthon, Desain Ilmu Dakwah (Yogyakarta: Pustaka Belajar dan Walisongo Pers, 2003), 142

2 Abdul Basit, Filsafat Dakwah (Jakarta: Rajawali Pers, 2013), 211 
keikhlasan, istiqomah, akhlak, nilai kedisiplinan, nilai kejujuran, nilai kerja keras, nilai kebersihan, nilai kompetisi, dan nilai solidaritas (kekeluargaan).

Tugas dakwah Islaminyah merupakan tanggung jawab seluruh umat Islam, baik secara individual maupun kolektif, sebagaimana termaktub dalam Al-Qur'an, Surat Yusuf, ayat 108 yang berbunyi:

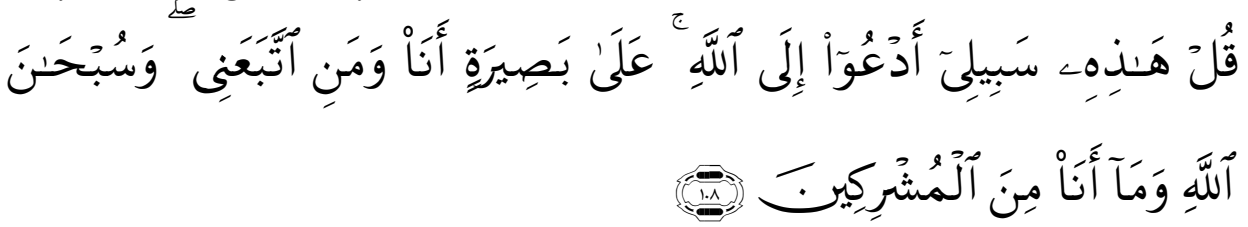

"Katakanlah: "Inilah jalan (agama) ku, aku dan orang-orang yang mengikutiku mengajak (kamu) kepada Allah dengan bujjah yang nyata, Maha suci Allah, dan aku tiada Termasuk orang-orang yang musyrik".'(QS. Yusuf:108).3

Ayat diatas menjelaskan bahwa Rasul diperintahkan oleh Allah untuk menyatakan bahwa berdakwah merupakan jalan hidupnya dan ayat tersebut juga melibatkan orang-orang mengikuti beliau, yaitu Umat Islam, baik secara individual maupun secara kolektif. Maka setiap umat Islam harus memiliki semangat dakwah kapan, dimana dan dalam kondisi apa pun.

Kerusakan mental dan spiritual masyarakat, khususnya para pemuda generasi penerus bangsa, sangat memperihatinkan peneliti. Dengan berbagai macam perkembangan teknologi zaman sekarang, tentu bukan hanya tenaga pendidik secara formal yang memperhatikan perkembangan, karakter dan akhlak anak-anak dan remaja saat ini, melainkan perhatian yang serius dari orang tua dan pendidikan non formal seperti dalam Yayasan Perguruan Bela Diri Muda Berakhlak. Hal tersebut dapat dilihat dari maraknya penyalah gunaan media internet yang bisa kapan saja di akses oleh anakanak dan remaja saat ini, dengan adanya Android (Gadget) super canggih zaman sekarang tentu orang tua harus berperan aktif dalam mendidik anak-anak dan remaja tersebut.

Bela diri sebagai suatu peninggalan budaya leluhur bangsa merupakan sebuah seni bela diri yang khas sesuai dengan kepribadiaan bangsa Indonesia. Keberadaan pencak silat pada hakikatnya adalah sebuah budidaya kepribadian bangsa Indonesia yang di dalamnya selain mengandung unsur bela diri, juga terdapat unsur seni, olahraga, dan spiritual bergabung menjadi satu kesatuan yang padu dan tidak dapat dipisahkan. Yayasan muda berakhlakadalah salah satu perguruan bela diri yang tergabung dalam Ikatan Pencak Silat Indonesia yang di singkat dengan nama IPSI. Berdasarkan prinsip dakwah, yayasan bela diri muda berakhlak selalu melaksanakan konsep belajar sambil melakukan (learning by doing) bagi setiap kader dan anggotanya. Sambil belajar mengenal dan menghafal gerakan atau jurus-jurus bela diri muda berakhlak, para kader juga di bina tentang penguatan aqidah, akhlaq (moralitas) dalam pegaulan, ketahanan mental serta kepemimpinan (leadership).

\footnotetext{
${ }^{3}$ Departemen Agama RI, Al-Qur'an dan terjemabannya (Semarang: Toha Putra, 1989), 186
} 
Di setiap latihan dan mendidik, penanaman ajaran Islam seolah tidak dirasakan secara langsung oleh para kader dan anggotanya. ${ }^{4}$ Semua proses indoktrinasi pengajaran Islam di laksanakan secara terselubung. Karena dakwah yang di laksanakan perguruan bela diri muda berakhlaksenantiasa menekankan aspek belajar (agama Islam) sambil bermain (berlatih jurus-jurus) Bela diri muda berakhlak merupakan Yayasan yang mengemban misi dakwah, dalam membentuk karakter para anak-anak, remaja, orang dewasa dan masyarakat, yang menjujung tinggi ajaran Islam Nusantara. ${ }^{5}$

\section{Rumusan Masalah}

Adapun rumusan masalah tentang problematika anak-anak dan remaja di Indonesia, serta peran Yayasan Perguruan Bela Diri Muda Berakhlak sebagai aktivitas dan pencerahan dakwah, dapat dirumuskan permasalahan sebagai berikut:

1. Bagaimana aktivitas dakwah Yayasan Perguruan Bela Diri Muda Berakhlak dalam membentuk akhlak anak-anak dan remaja di perguruan tersebut?

2. Bagaimana nilai-nilai dakwah yang dikembangkan dan diterapkan dalam Yayasan Perguruan Bela Diri Muda Berakhlak terhadap anak-anak dan remaja tersebut?

3. Apa saja faktor pendukung dan penghambat dakwah Yayasan Perguruan Bela Diri Muda Berakhlak?

\section{Kajian Teori}

\section{Tinjauan tentang Nilai-nilai Dakwah}

\section{Pengertian Nilai}

Nilai sangat erat kaitannya dengan norma, karena nilai yang dimiliki seseorang ikut mempengaruhi perilakunya. Norma sebenarnya mengatur perilaku manusia yang berhubungan dengan nilai yang terdapat dalam suatu kelompok, yang berarti untuk menjaga agar nilai-nilai kelompok itu tidak diperlakukan seenaknya, maka disusunlah norma-norma untuk menjaga nilai-nilai tersebut. Adapun definisi norma itu sendiri menurut Herwantiyoko dan Neltje F. Katuuk adalah patokan perilaku dalam suatu kelompok tertentu. Norma memungkinkan seseorang untuk menentukan terlebih dahulu bagaimana tindakannya itu akan dinilai oleh orang lain, dan norma ini merupakan kriteria bagi orang lain untuk mendukung atau menolak perilaku seseorang. 6

Dalam kamus Bahasa Indonesia, nilai dapat diartikan sebagai harga atau jika dikaitkan dengan budaya berarti konsep abstrak yang mendasar, sangat penting dan bernilai bagi kehidupan manusia. Menurut Onong Uchjana Effendy, nilai adalah pandangan, cita-cita, adat kebiasaan dan lain-lain yang menimbulkan tanggapan

\footnotetext{
${ }^{4}$ Andri Hermawan,Wawancara, Guru Besar Muda Berakblak, 05 Februari 2018

${ }^{5}$ Sabar, Wawancara, Pengurus Yayasan Perguruan Bela Diri Muda Berakblak, 05 Februari 2018

${ }^{6}$ Herwantiyoko dan Neltje F. Katuuk, Pengantar Sosiologi dan Ilmu Dasar Sosial (Jakarta: Gunadarma, 1996), Edisi Pertama, Cet. Ke-I, 5
} 
emosional pada seseorang atau masyarakat tertentu. Sementara, menurut Fraenkel, nilai merupakan sebuah ide atau konsep mengenai sesuatu yang dianggap penting dalam kehidupan ketika seseorang menilai sesuatu, maka orang tersebut menganggap nilai itu penting, bermanfaat, atau berharga. ${ }^{7}$

\section{Pengertian Dakwah}

Secara etimologis, dakwah berasal dari bahasa Arab, yaitu da'a, yad'u, da'wan, $d u^{\prime} a$, yang diartikan sebagai mengajak/menyeru, memanggil, seruan, permohonan, dan permintaan. ${ }^{8}$ Istilah ini sering diberi arti yang sama dengan istilah-istilah tabliq, amr ma'ruf dan nahi munkar, mau'idzhoh hasanah, tabsyir, indzhar, washiyah, tarbiyah, ta'lim, dan khotbah. ${ }^{9}$

Dakwah adalah mengajak manusia dengan cara bijaksana kepada jalan yang benar yang sesuai dengan perintah Tuhan untuk kemaslahatan dan kebahagiaan manusia di dunia dan di akhirat. Dalam Islam posisi dakwah sangatlah penting karena dakwah merupakan kegiatan yang berperan secara langsung dalam pembentukan persepsi umat tentang berbagai nilai kehidupan. Dakwah juga merupakan kegiatan untuk mengadakan rekonstruksi sosial untuk didesain dan dipolakan oleh ajaran Islam serta mentransformasikan nilai-nilai atau syariat Islam kepada masyarakat, sehingga tercapai pembentukan masyarakat yang sesuai dengan kehendak Allah. ${ }^{10}$

Dakwah adalah suatu aktivitas yang berorientasi pada pengembangan masyarakat muslim, dalam pengertian agama, dakwah mengandung arti panggilan dari Allah dan Nabi untuk umat manusia agar percaya kepada ajaran Islam dan mewujudkan ajaran yang dipercayainya itu kedalam segala aspek kehidupan. Kecenderungan pemaknaan dakwah ini tidak perlu di pertentangkan karena sasaran dibalik dakwah itu sendiri pada dasarnya tidak saja ditunjukkan kepada non muslim akan tetapi kepada yang muslim. Bagi yang muslim dakwah berfungsi sebagai proses peningkatan kualitas keimanan dalam penerapan ajaran-ajaran agamanya dalam kehidupan. ${ }^{11}$

\section{Nilai-nilai Dakwah}

Nilai-nilai dakwah, yakni nilai-nilai Islam yang bersumber dari Al-Qur'an dan Hadits. Nilai-nilai dakwah bukanlah suatu "barang yang mati", melainkan nilai dinamis yang disesuaikan dengan semangat zaman dan perkembangan ilmu pengetahuan yang ada dimasyarakat. Menurut Muhamad Sulthon, tata nilai Islami yang terdapat di dalam Al-Qur'an bersifat historis, dinamis, dialektis, dan profetik-

\footnotetext{
${ }^{7}$ Abdul Basit, Filsafat Dakwah (Jakarta: Rajawali Pers, 2013), 194

${ }^{8}$ Muhammad Sulthon, Desain Ilmu Dakwah (Yogyakarta: Pustaka Pelajar, 2003), 4

${ }^{9}$ M. Munir dan Wahyu Ilahi, Manajemen Dakwah (Jakarta: Kencana, 2009), 17

${ }_{10}$ Abdul Rahman, Metode Dakwah (Curup: LP2 STAIN Curup, 2010), 17

${ }^{11}$ Abdul Rahman, Metode Dakwah, 18
} 
transformatif. ${ }^{12}$ Menurut Abdul Basit, bahwa nilai adalah pandangan, cita-cita, adat kebiasaan dan lain-lain yang menimbulkan tanggapan emosional pada seseorang atau masyarakat tertentu. ${ }^{13}$ Sementara menurut Fraenkel, Abdul Basit juga mengkutip nilai merupakan sebuah ide atau konsep mengenai sesuatu yang dianggap penting dalam kehidupan ketika seseorang menilai sesuatu, maka orang tersebut menganggap nilai itu penting, bermanfaat atau berharga. ${ }^{14}$

Nilai-nilai yang terdapat di dalam Al-Qur'an perlu didialogkan dengan kenyataan yang ada pada masyarakat (manusia) sebagai pengembang amanah di muka bumi ini. Al-Qur'an itu baru memiliki makna bagi manusia jikalau Al-Qur'an itu sudah melekat di dalam pikiran manusia dan diwujudkan dalam tindakan nyata. Untuk mewujudkan hal tersebut, seorang da'i perlu menginternalisasikan nilai-nilai dakwah dalam dirinya, sehingga pesan-pesan dakwah yang akan disampaikannya akan mempertimbangkan nilai-nilai dakwah tersebut dan kegiatan dakwah berjalan sesuai dengan apa yang diharapkan. ${ }^{15}$

Dalam praktik di lapangan, ada tiga macam nilai yang perlu dikembangkan karena ketiga nilai tersebut memengaruhi kita dan jika kita tidak akui keberadaannya, maka akan mengalami konflik dalam diri kita antara lain:

1) Nilai universal. Nilai universal berlaku untuk semua manusia. Faktanya kita semua mempunyai jiwa kemanusiaan dan jiwa spiritual. Nilai universal adalah aspek-aspek kesadaran atau kualitas jiwa yang memancar dari diri kita. Nilai universal ini tidak mudah diwujudkan secara konsisten karena lebih bersifat pribadi. Nilai universal berlawanan dengan nilai budaya.

2) Nilai budaya. Nilai budaya adalah nilai-nilai yang ada di masyarakat atau budaya yang dimiliki oleh masyarakat. Nilai budaya tidak bersifat universal dan tidak bersifat personal, melainkan bersifat kolektif. Keberadaanya bukan karena kesadaran melainkan karena pengaruh orang.

3) Nilai personal adalah hasil dari pengkondisian dan tingkat kesadaran kita. Nilai personal dapat dinilai dari kepribadian atau dari jiwa seseorang. Nilai personal dapat menjadi egois, terbatas dan sangat kondisional.

Tindakan yang dilakukan oleh umat Islam mestinya dibangun dari pemahaman yang komprehensif tentang ajaran Islam yang di dalamnya terdapat nilai-nilai dakwah yang bersifat universal. Beberapa nilai-nilai dakwah universal yang dapat diaplikasikan dalam kehidupan umat, diantaranya sebagai berikut:

\section{a. Kedisiplinan}

Kedisiplinan tidak diartikan dengan kehidupan yang kaku dan susah tersenyum. Kedisiplinan terkait erat dengan manajemen waktu. Bagaimana waktu yang diberikan oleh Tuhan selama 24 jam dalam sehari dapat dimanfaatkan

12 Muhamad Sulthon, Desain Imu Dakwah (Yogyakarta: Pustaka pelajar dan Walisongo Press, 2003), 144

${ }^{13}$ Abdul Basit, Filsafat Dakwah (Jakarta: Direktorat Pendidikan Tinggi Islam Kementerian Agama RI, 2012), 258-259

${ }^{14}$ Abdul Basit, Filsafat Dakwah, 259

${ }^{15}$ Abdul Basit, Filsafat Dakwah, 195 
dengan sebaik-baiknya untuk meraih kesuksesan di dunia dan akhirat. Al-qur'an banyak sekali ayat yang menyebutkan tentang pentingnya waktu, seperti demi masa (wal'ashr), demi waktu dhuha (waddhuha), demi waktu malam (wallaili), demi waktu fajar (walfajr), dan lain sebagainya.

\section{b. Kejujuran}

Rasulullah merupakan teladan utama dalam kejujuran dan bahkan beliau memiliki sifat sidiq (jujur). Sebagaimana Rasulullah memerintahkan umatnya untuk berlaku jujur. Kita bisa belajar dari umat yang dibinasakan oleh Allah akibat tidak jujur dan kejahatan lain yang dilakukannya, yaitu pada bangsa Madyan.

\section{c. Kerja Keras}

Allah dalam beberapa ayat mendorong umat-nya untuk bekerja keras seperti di jelaskan dalam QS Al-Jumu'ah 62:10 sebagai berikut yang artinya:

"Apabila telah ditunaikan shalat, Maka bertebaranlah kamu di muka bumi; dan carilah karunia Allah dan ingatlah Allah banyak-banyak supaya kamu beruntung". (QS AlJumu'ab 62:10)

Begitu pun, Nabi telah mencontohkan sejak kecil sudah bekerja keras: mengembala kambing, berdagang, dan berupaya sekuat tenaga untuk membebaskan umat (kaum dhufa) dari kemiskinan, kebebasan, perbudakan, eksploitasi kaum aghniya, dan sebagainya. Nabi mengingatkan kita "Yang paling aku khawatirkan dan takuti terhadap umatku adalah suka membusungkan dada, banyak tidur dan malas bekerja.

\section{d. Kebersihan}

Umat Islam sangat hapal sekali dengan hadits Nabi yang menyatakan bahwa "kebersihan adalah sebagian dari iman" (H.R Muslim). Sayangnya, hapalan tersebut kurang diimbangi dengan praktik di lapangan. Realitas tempattempat umum milik umat Islam menunjukkan kurang terjaganya kebersihan, seperti masjid, mashala, pondok pesantren, asrama haji, majelis taklim dan lain sebagainya. Kebersihan masih dianggap sebagai kewajiban dari tugas kebersihan. Kesadaran diri masing-masing individu untuk menjaga kebersihan masih amat minim. Allah swt mengingatkan umat Islam untuk menjaga kebersihan (kesucian) jiwa dan juga kebersihan yang bersifat fisik, dengan simbol untuk membersihkan pakaian. Dengan demikian, menjaga kebersihan merupakan nilai dakwah universal yang dapat dilakukan oleh siapa saja, apalagi umat Islam yang jelas-jelas memiliki sadar kuat untuk menjaga kebersihan. 


\section{e. Kompetisi}

Islam tidak melarang umatnya untuk berkompetisi, karena kompetisi merupakan salah satu motivasi psikologis yang sangat umum dimiliki oleh setiap manusia. Setiap mahasiswa akan memiliki motivasi untuk berkompetisi di antara teman-temannya. Meskipun masing-masing individu berbeda-beda dalam tingkat motivasinya. Nilai-nilai dakwah yang berlaku universal tersebut senantiasa disosialisasikan kepada masyarakat sehingga nilai-nilai tersebut menjadi kebiasaan, tradisi, atau norma yang berlaku di masyarakat. Jika nilai-nilai dakwah universal telah berkembang dan menjadi norma di masyarakat, maka nilai-nilai dakwah telah memasuki tahap institusionalisasi atau pelembagaan. Sebelum kita lebih memahami lebih jauh bagaimana proses institusionalisasi tersebut berlangsung, maka terlebih dahulu akan diperkenalkan tentang institusi.

\section{Metode Penelitian}

\section{Jenis Penelitian}

Dalam penelitian ini penulis menggunakan pendekatan deskriptif kualitatif. Pendekatan ini digunakan karena data yang dibutuhkan penulis dalam menyusun skripsi ini hanya berupa keterangan, penjelasan, dan informasi-informasi yang berkaitan dengan objek yang diteliti. Pendekatan kualitatif merupakan suatu cara untuk mendapatkan data atau informasi mengenai persoalan-persoalan yang terjadi dilapangan atau dilokasi penelitian. Pada penelitian tersebut yang dilakukan ini dilihat dari segi tujuan adalah penelitian deskriptif kualitatif. Data kualitatif merupakan data yang berupa informasi, uraian dalam bentuk bahasa prosa kemudian dikaitkan dengan data lainnya untuk mendapatkan kejelasan terhadap suatu kebenaran atau sebaliknya. ${ }^{16}$ Dalam menggunakan data kualitatif terutama dalam penelitian dipergunakan untuk informasi yang bersifat menerangkan dalam bentuk uraian. ${ }^{17}$

\section{Subjek Penelitian}

Penelitian ini adalah penelitian kualitatif sehingga diperlukan subjek atau informan penelitian. Yang dimaksud subjek atau informan penelitian adalah benda, orang, tempat dan data untuk variabel yang dipermasalahkan. ${ }^{18}$ Subjek penelitian merupakan segala sesuatu yang dapat di jadikan sebagai sumber data. Dalam pengambilan dan pengumpulan sumber data dilapangan yang di jadikan sebagai subjek penelitian adalah orang-orang yang mempunyai data terkait informasi yang penulis butuhkan.

106

16 Subagio Joko, Metode Penelitian Dan Teori Dalam Praktek (Jakarta: Rineka Cipta, 1991),

${ }^{17}$ Subagio Joko, Metode Penelitian Dan Teori Dalam Praktek, 94

18 Suharsimi Arikunto, Prosedor Penelitian Suatu Pendekatan Praktis (Jakarta: Rineka Cipta, 1998), 121 


\section{Sumber Data}

Penelitian ini adalah penelitian lapangan fild research dengan menggunakan metode deskriptif kualitatif dengan tujuan untuk membuat deskriptif kualitatif secara sistematis factual dan akurat mengenai fakta-fakta dan sifat-sifat populasi atau daerah tertentu. ${ }^{19}$ Maka penulis menggunakan data kualitatif. Data penelitian ini terdiri dari:

\section{Data Primer}

Data primer adalah data utama yang diperlukan oleh peneliti dimana data yang langsung dikumpulkan dari objek penelitian. Data primer ini diperoleh langsung dari wawancara yang diajukan kepada responden yang dikumpulkan dan diolah sendiri oleh peneliti secara langsung dari objeknya. ${ }^{20}$ Dalam hal ini yang menjadi sumber data primer meliputipimpinan Yayasan Muda Berakhlak, pengawas Yayasan Muda Berakhlak, pembina/penasehat Yayasan Muda Berakhlak, Guru Besar Perguruan Bela Diri Muda Berakhlak, pengurus harian Yayasan Perguruan Bela Diri Muda Berakhlak, Pelatih Perguruan Bela Diri Muda Berakhlak, serta kader dan anggota Perguruan Bela Diri Muda Berakhlak di Kabupaten Lebong.

2. Data Sekunder

Data sekunder adalah data tambahan sebagai penguat dari data primer yang telah dikumpulkan oleh peneliti. Dalam hal ini data sekunder dapat diperoleh dari pihak yang mempunyai hubungan langsung dengan objek penelitian, yaitu anggota dan kader Perguruan Bela Diri Muda Berakhlak, orang tua dari murid Perguruan Bela Diri Muda Berakhlak, masyarakat yang ada di Desa Danau Kecamatan Lebong Atas, dan Instansi terkait yang ada di Kecamatan Lebong Atas.Selain itu data sekunder meliputi buku-buku atau literatur yang relevan dan menunjang secara teoritik terhadap penelitian yang dilaksanakan. ${ }^{21}$

\section{Teknik Pengumpulan Data}

Dalam penelitian kualitatif, kualitas riset sangat tergantung pada kualitas dan kelengkapan data yang di hasilkan. Pertanyaan yang selalu diperhatikan dalam pengumpulan data adalah apa, siapa, dimana, kapan, dan bagaimana.penelitian kualitatif bertumpu pada triangulation data yang dihasilkan dari tiga metode: interview, participant ob servation, dan telah catatan organisasi (document records). ${ }^{22}$

Agar mendapatkan data yang relevan dan valid terkait permasalahan yang diangkat dalam penelitian ini, maka penulis mengunakan beberapa metode, yaitu:

\footnotetext{
${ }^{19}$ Burhan Bungin, Metode Penelitian Kualitatif, (Jakarta: Raja Grafindo Persada, 2006), 88

${ }^{20}$ Burhan Bungin, Metode Penelitian Kualitatif, ... 88-89

${ }^{21}$ Burhan Bungin, Metode Penelitian Kualitatif, (Jakarta: Raja Grafindo Persada, 2006), 88

22 Sukarman Syarnubi, Metode Penelitian Kuantitatif dan Kualitatif, (Curup: LP2 STAIN
} Curup, 2011), 183 


\section{Observasi}

Nasution sebagaimana yang dikutip Sugiyono menyatakan bahwa observasi adalah dasar semua ilmu pengetahuan. Artinya penelitian sesuai dengan fakta dan kenyataan yang ada di lapangan yang di peroleh melalui observasi. Dan data yang di dapat kumpulkan. ${ }^{23}$ Observasi merupakan alat pengumpulan data yang dilakukan dengan cara mengamati dan mencatat gejala-gejala yang diselidiki. Dalam pengertian lain dikatakan "observasi disebut juga dengan pengamatan, meliputi kegiatan pemusatan perhatian terhadap suatu obyek dengan menggunakan seluruh alat indra". ${ }^{24}$ Dengan teknik observasi partisipan diharapkan dapat dijaring keteranganketerangan empiris yang detail dan aktual dari unit analisis penelitian, apakah itu menyangkut kehidupan individu maupun unit-unit sosial tertentu dalam masyarakat. ${ }^{25}$

Observasi digunakan untuk memperoleh data secara langsung mengenai nila-nilai dakwah yang dikembangkan oleh Yayasan Muda Berakhlak dengan mengamati secara langsung pada kegiatan-kegiatan yang dilaksanakan, berupa latihan secara rutin, pengkaderan, dan yang lainya di Perguruan Bela Diri Muda Berakhlak Kabupaten Lebong. Dengan demikian peneliti dapat menegtahui bagaimana bimbingan keagamaan yang ditanamkan didalam setiap kegiatan Yayasan Perguruan Bela Diri Muda Berakhlak.

\section{Wawancara}

Wawancara adalah metode pengumpulan data yang dilakukan dengan cara dialog antar dua orang atau lebih dengan cara bertatap muka untuk memperoleh informasi yang diperlukan. ${ }^{26}$ Pada penelitian ini wawancara akan dilakukan dengan menggunakan pedoman wawancara. Jenis wawancara yang digunakan dalam penelitian ini dalam kategori dept interview (wawancara mendalam) yang menurut Sugiyono (2005) di lakukan secara semi struktur. Maksudnya peneliti dalam melaksanakan wawancara mengunakan paduan wawancara yang berisi butir-butir pertanyaan yang akan di ajukan kepada informan. Metode ini dipilih karena dua alasan. Pertama, peneliti dapat menggali tidak hanya yang di ketahui dan di alami subyek yang diteliti, namun juga hal-hal yang tersembunyi jauh didalam diri subyek. Kedua, apa yang ditanyakan kepada informan bisa mencangkup hal-hal yang bersifat lintas waktu, yang berkaitan dengan masa lalu, saat ini, atau masa yang akan datang.

Wawancara bertujuan mencatat opini, perasaan, emosi, dan hal lain berkaitan dengan individu yang ada dalam organisasi. Dengan melakukan wawancara, peneliti dapat memperoleh data yang lebih banyak sehingga peneliti

${ }^{23}$ Sugiyono, Metode Penelitian KuntitatifKualitatif, R dan D (Bandung: Alfabeta, 2014), 226

24 Arikunto, Suharsimi Prosedur Penelitian (Jakarta:Rineka Cipta, 2002), 206

${ }^{25}$ Burhan Bungin, Analisis Data Penelitian Kualitatif (Jakarta: Raja Grafindo Persada, 2006) 26

${ }^{26}$ Hardadi Nawawi dan M. Martini, Instrument Penelitan Bidang Sosial (Yogyakarta: Gajah Mada Uniprisiti Prees, 1992), 201 
dapat memahami budaya melalui bahasa dan ekspresi pihak yang di wawancarai, dan dapat melakukan klarifikasai atas hal-hal yang tidak diketahui.

3. Dokumentasi

Dokumen adalah rekaman peristiwa yang lebih dekat dengan percakapan, menyangkut persoalan pribadi, dan memerlukan interpretasi yang berhubungan sangat dekat dengan konteks rekaman peristiwa tersebut. ${ }^{27}$ Menurut Suharmi Arikunto (2006), dokumentasi adalah barang tertulis. Yang dapat berupa catatan atau tulisan, transkrip, buku-buku, surat kabar, majalah, notulen rapat, agenda dan sebagainya.

Dalam hal ini penulis menggunakan dokumentasi agar dapat menemukan data yang memang diperlukan. Dokumentasi ini sebagai pelengkap dari pengunaaan metode observasi dan wawancara. Metode ini digunakan untuk memperoleh data terkait Perguruan Bela Diri Muda Berakhlak Kabupaten Lebong, berupa profil perguruan Muda Berakhlak, arsip-arsip, lambang-lambang, photo, serta dokumen yang berkaitan.

\section{Teknik Analisis Data}

Analisis data dalam penelitian berlangsung bersamaan dengan proses pengumpulan data. Di antaranya adalah melalui tiga tahap model air, yaitu reduksi data, penyajian data, dan verifikasi. Namun, ketiga tahapan tersebut berlangsung secara simultan. ${ }^{28}$

Analisa data dalam penelitian ini dilakukan dengan menggunakan dua metode, antara lain:

a) Metode deduktif, yaitu proses pendekatan yang berangkat dari kebenaran umum yang menjelaskan suatu fenomena, fakta dan realita yang terjadi.

b) Metode induktif, yaitu proses logika yang berasal dari data empiric melalui observasi menuju suatu teori. ${ }^{29}$ Selanjutnya di kembangkan menjadi hipotesis.

Analisis data dalam penelitian ini, dilakukan dengan kegiatan sebagai berikut.

1. Pengumpulan Data

Pengumpulan data yaitu data yang diperoleh dari hasil wawancara, observasi, dokumentasi dan studi kepustakaan dicatat dalam catatan lapangan yang terdiri dari dua bagian yaitu deskriptif dan reflektif. Catatan deskriptif adalah catatan alami, catatan apa yang dilihat, didengar, disaksikan sendiri oleh penulis tanpa adanya pendapat dan penafsiran dari penulis terhadap fenomena yang dialami. Data diperoleh dari interviu open-ended yang panjang dimana peneliti merekam dan

${ }^{27}$ Burhan Bungin, Metodologi Penelitian Kualitatif, (Jakarta: Rajawali Pers, 2010), 142-143

${ }^{28}$ Burhan Bungin, Metodologi Penelitian Kualitatif, ... 144

${ }^{29}$ Saifudin Azwar, Metode Penelitian,(Yogyakarta: Pustaka Pelajar, 2012), 36 
mentransfer data tersebut ke dalam transkip. Peneliti juga meneliti artifak-artifak seperti buku catatan yang ditunjukkan partisipan kepadanya. ${ }^{30}$

2. Reduksi Data

Setelah data terkumpul, selanjutnya dibuat reduksi data, guna memilih data yang relevan dan bermakna, memfokuskan data yang mengarah untuk memecahkan masalah, penemuan, pemaknaan atau untuk menjawab pertanyaan penelitian yang telah disusun dalam rumusan masalah. Kemudian penyederhaan dan penyusunan secara sistematis dan manjabarkan hal-hal penting tentang hasil temuan peneliti dari keadaan di lapangan. Dengan kata lain reduksi data digunakan untuk analisis yang menajamkan, menggolongkan, mengarahkan dan membuang yang tidak penting, serta mengorganisasikan data, sehingga memudahkan penulis untuk menarik kesimpulan.

3. Penyajian Data

Penyajian data dapat berupa tulisan atau kata-kata, gambar, grafik dan tabel. Tujuan sajian data adalah untuk menggabungkan informasi sehingga dapat mengambarkan keadaan yang terjadi. Dalam hal ini, agar peneliti tidak kesulitan dalam penguasaan informasi baik secara keseluruhan atau bagian-bagian tertentu dari hasil penelitian, maka penulis harus membuat naratif, matrik atau grafik untuk memudahkan penguasaan informasi atau data tersebut.

4. Penarikan Kesimpulan

Penarikan kesimpulan dilakukan selama proses penelitian berlangsung seperti halnya proses reduksi data, setelah data terkumpul cukup memedai maka selanjutnya diambil kesimpulan sementara, dan setelah data benar-benar lengkap maka diambil kesimpulan akhir. Sesuai dengan tujuan yang ingin dicapai dalam hasil penelitian ini, maka analisis dan penarikan kesimpulan dilakukan dengan jalan membandingkan data yang diperoleh.

Dalam penelitian ini data-data yang sudah didapatkan sebelumnya, kemudian peneliti bandingkan dengan data-data hasil wawancara dengan subyek dan informan yang bertujuan untuk menarik kesimpulan. Data tersebut dianalisis dengan metode Induktif. Metode induktif merupakan berpikir dari keputusan atau kesimpulan khusus untuk memperoleh kesimpulan umum. ${ }^{31}$

30 Asmadi Alsa, Pendekatan Kuantitatif \& Kualitatif Serta Kombinasinya Dalam Penelitian Psikologi, (Yogyakarta: Pustaka Pelajar, 2011), Cet. Ke-V, 141

${ }^{31}$ Komaruddin, Kamus Istilah Skripsi dan Tesis, (Angkasa, Bandung: 1985), 29 
70 |Jurnal Dakwah dan Komunikasi, Vol. 4 , No. 1 , 2019

\section{Hasil Penelitian dan Pembahasan}

\section{Kondisi Umum Wilayah Penelitian}

\section{Sejarah Berdirinya Yayasan Perguruan Bela Diri Muda Berakhlak}

Perguruan Bela Diri "Muda Berakhlak" diawali risalah perjalanan seorang perintis bela diri yang bernama Andri Hermawan. Beliau adalah salah seorang yang memperdalam ilmunya dibeberapa perguruan bela diri diantaranya seni bela diri Padjajaran merupakan pewaris seni bela diri yang berasal dari tanah Jawa Barat, yang terkenal dengan jurusan lima (Panca Dirya Pra Pencak Silat) selain dari itu dari beberapa pondok pesantren di daerah Jawa Barat juga ikut berkontribusi memperdalam ilmu bela diri. Salah seorang guru yang membimbing beliau adalah bapak Tohsin seorang guru bela diri yang beraliran pencak silat Pasundan. Kemudian beliau menggabungkan inti sari dari semua bela diri yang pernah dipelajarinnya termasuk hasil oleh bathin dan perjalanan Napak Tilas (Ziarah) di makam-makam Wali Songgo. ${ }^{32}$

Sejarah bela diri muda berakhlak lahir pada saat seorang pendekar dari Jawa bermana Andri Hermawan seorang guru dari beberapa pondok pesantren yang mengembara ke pulau sumatera tepatnya di Kabupaten Lebong Provinsi Bengkulu.Dalam perjalanan beliau menetap di Kabupaten Lebong tepatnya di Provinsi Bengkulu dan kemudian pada tanggal 16 april 2016 beliau resmi mendirikan sebuah Yayasan Muda Berakhlak yang baru diberi nama "Perguruan Bela Diri Muda Berakhlak Indonesia" dengan tujuan untuk mengembleng generasi muda khususnya di Kabupaten Lebong yang berakhlak mulia melalui seni bela diri. Dengan penyempurnaan tersebut "Perguruan Bela Diri Muda Berakhlak" terus berkiprah untuk perkembangan kekayaan seni kebudayaan asli bangsa Indonesia. pencerminan:

Lambang perguruan Bela Diri "Muda Berakhlak" mewujudkan

a. Berani yang mencerminkan dengan warna merah;

b. Bersikap kesatria dalam penegakkan keadilan dan kebenaran yang di simbolkan dengan gambar kepala harimau/macan;

c. Suci di simbolkan berwarna putih. ${ }^{33}$

\section{Visi dan Misi Yayasan Perguruan Bela Diri Muda Berakhlak}

a. Visi Perguruan Bela Diri Muda Berakhlak

Melestarikan dan mengembangkan Bela Diri sehingga menjadi kebanggaan dan menjadikan jati diri bangsa Indonesia.

b. Misi Perguruan Bela Diri Muda Berakhlak

1) Mengembangkan dan melestarikan kebudayaan bangsa Indonesia, khususnya olah raga Bela Diri "Muda Berakhlak".

32 Andri Hermawan, Wawancara, Pimpinan Yayasan Perguruan Bela Diri Muda Berakhlak, 15 Desember 2017

${ }^{33} \mathrm{AD} / \mathrm{ART}$, Yayasan Perguruan Bela Diri Muda Berakblak, 2 
2) Turut serta membangun masyarakat Indonesia seutuhnya yang bertaqwa kepada Tuhan yang maha esa, sehat jasmani dan rohani, berjiwa patriot, setia kawan serta berakhlak mulia.

3) Mengingkatkan kesejahteraan para praktisi pencak silat melalui bela diri itu sendiri. ${ }^{34}$

\section{Stuktur Pengurus Yayasan dan Anggota Perguruan Bela Diri Muda Berakhlak} lain:

Susunan pengurus Yayasan Perguruan Bela Diri Muda Berakhlak antara

$\begin{array}{ll}\text { Pimpinan Yayasan } & \text { : Andri Hermawan } \\ \text { Pembina/Penasehat } & : \text { Bendra Wardana } \\ \text { Ketua Perguruan } & : \text { Sabar Angga Pratama } \\ \text { Sekretaris } & : \text { Yulis } \\ \text { Bendahara } & : \text { Riski Syamsudin } \\ \text { Dewan Pelatih } & : \text { Fauzi } \\ \text { Humas } & : 1 . \text { Amin Syasudin } \\ & : 2 . \text { Subowo } \\ \text { Devisi Pengembangan } & : \text { Kader MBM }\end{array}$

\section{Program Yayasan Perguruan Bela Diri Muda Berakhlak}

a. Bela Diri (Wadah mengembangkan bakat dan budaya Indonesia)

Perguruan seni bela diri adalah pencak silat yang merupakan suatu budaya bangsa yang luhur dan bermoral, yang perlu di lestarikan, ditumbuh kembangkan dan di amalkan serta di jauhkan dari hal-hal yang berbau syirik dan menyesatkan yang dapat menodai nilai-nilai keimanan didalamnya. Bela diri adalah sebagai media dakwah dalam membina akhlak anak-anak dan remaja baik yang tergabung dalam perguruan bela diri maupun yang ada di Kecamatan Lebong Atas Kabupaten Lebong. Maka dari itu di jadikanlah Perguruan Bela Diri Muda Berakhlak sebagai alat atapun perantara dalam mendidik dan membina anak-anak dan remaja tersebut. Dalam hal ini, bela diri juga di katakan sebagai wadah dalam menyampaikan pesan-pesan dakwah atau nilai-nilai keislaman terdahap anak-anak dan remaja yang ada di Kabupaten Lebong.

Dalam membina dan mendidik anak-anak dan remaja tentu sebuah Yayasan Perguruan Bela Diri harus membuat strategi yang matang bagaimana orang tua dari anak-anak dan remaja tertarik untuk bergabung dan di jadikan lah Perguruan Bela Diri Muda Berakhlak sebagai wadah dan media dalam

${ }^{34}$ Document, Perguruan Bela Diri Muda Berakblak, Tahun 2018 
menyampaikan pesan-pesan dakwah dan nilai-nilai keislaman itu baik kepada masyarakat khusus nya maupun anak-anak dan remaja yang tergabung dalam perguruan bela diri tersebut. ${ }^{35}$

\section{b. Pengobatan Sesuai Syariat Islam (Ruqiah)}

Selain dari Perguruan Bela Diri Muda Berakhlak sebagai media atau wadah dalam menyampaikan pesan-pesan dakwah atau nilai-nilai islamiyah, Guru besar dan pengurus juga membuka pengobatan dan terapi sesuai syariat Islam yaitu (Ruqiah), dalam hal ini pengobatan dan terapi dibuka di Pusat Yayasan Muda Berakhlak Desa Danau Kecamatan Lebong Atas Kabupaten Lebong, bukan masyarakat Lebong saja yang berobat datang kesana melainkan banyak dari daerah atau kota lain yang berdatangan.

Orang yang datang mau berobat ke yayasan di anjurkan dahulu untuk shalat malam dan memperbanyak berzikir sesuai sakit yang dideritanya, karena tidak lain penyakit yang datang dari Allah dan kepadanya lah kita berdoa dan meminta kesembuhan.Cara dalam pengobatan kesehatan pasien yang kami gunakan yaitu sesuai syariat Islam adalah dibacakan ayat-ayat alquran dan doadoa yang mengandung permintaan tolong dan perlindungan kepada Allah Subhanahu Wa Ta'ala untuk mencegah dan mengobati bala dan penyakit. Yang tidak lain lazim disebut dengan Ruqiah dan terapi sesuai syariat Islam dan yang di contohkan Rasulullah SAW. ${ }^{36}$

\section{Hasil Penelitian}

\section{Aktivitas Dakwah Yayasan Perguruan Bela Diri Muda Berakhlak}

\section{a. Berzikir}

Berzikir adalah mengingat kepada Allah SWT dan senantiasa dekat dengannya. Dengan senantiasa mengingat Allah SWT dan dekat dengannya akan membawa kita kepada kebaikan. Seorang muslim yang selalu berzikir akan diawasi setiap langkahnya dan gerak hatinya oleh Allah SW'T untuk terjaga dalam setiap langkah demi langkah yang dilakukan dalam kehidupannya. Berzikir merupakan obat untuk hati kita (manusia) yang membuat kita bersahaja, arif, tenang, dan damai.

Dalam menyampaikan nilai-nilai dakwah Perguruan Bela Diri Muda Berakhlak mengamalkan dzikir sebagai cara atau media mendekatkan diri kepada Allah SWT, dengan cara mengingat dan menyebut nama Allah SWT, serta dengan cara ini lah kader/murid dan anggota Perguruan Bela Diri Muda Berakhlak selalu imbangi dengan nilai-nilai keislaman. Kegiatan ini rutin dilaksanakan saat kenaikan tingkat sabuk dalam pengkaderan. Dalam hal ini Perguruan Bela Diri Muda Berakhlak juga memberikan hafalan dzikir untuk di

35 Ahmad Faizal, Wawancara, Pengurus Perguruan Bela Diri Muda Berakblak, 07 Januari 2018

36 Andri Hermawan, Wawancara, Pimpinan Yayasan Perguruan Bela Diri Muda Berakblak, 07 
amalkan oleh setiap kader dan anggota perguruan, amalan yang sering di gunakan dalam Perguruan Bela Diri Muda Berakhlak antara lain Tasbih, Takbir, Tahlil, Tahmid dan Istigfar. Tujuan dan manfaat dari Berdzikir agar kader dan anggota perguruan yang sudah mahir dalam ilmu bela diri tentu harus selalu mendekatkan diri kepada Allah SWT dengan cara berdzikir dan selalu mengingat Allah, bahwa ilmu itu datangnya dari Allah dan menghindari sifat sombong, angkuh dan seperti jagoan karena Allah akan murka kepadanya. Jadikan bela diri sebagai kegiatan olahraga dan latihan fisik untuk kesehatan dan berzikir untuk mendekatkan diri kepada Allah SWT. ${ }^{37}$ Setiap ujian dalam kenaikan sabuk tingkatannya seorang kader dan anggota perguruan selalu dibimbing serta dibina oleh guru besar dan dewan pelatih dalam mengamalkan zikir diantaranya bacaan tasbih, perbanyak istighfar dan lain sebagainya. Agar ilmu yang didapat dapat berguna, bermanfaat, dan terhindar dari sifat angkuh maupun sifat sombong. ${ }^{38}$

\section{b. Berdoa Sebelum dan Sesudah Latihan}

Doa adalah permohonan kepada Allah yang disertai kerendahan hati untuk mendapatkan suatu kebaikan dan kemaslahatan yang berada di sisi-Nya. Sedangkan sikap Khusyu' dan tadharru' dalam menghadapkan diri kepada-Nya merupakan hakekat pernyataan seorang hamba yang sedang mengharapkan tercapainya sesuatu yang dimohonkan. Itulah pengertian doa secara syar'i yang sebenarnya.

Perguruan Bela Diri Muda Berakhlak selalu menerapkan kepada kader dan anggota agar berdoa dahulu baik sebelum kegiatan maupun sesudah kegiatan latihan, karena dengan berdoa dan memohon kepada Allah agar menjadi suatu kebaikan dan menjadi ilmu yang bermanfaat baik bagi kesehatan dan cara mendekatkan diri bermunajat kepada Allah SWT. Tujuan berdoa sebelum kegiatan dan sesudah latihan adalah ibadah dan salah satu bentuk ketaatan kepada Allah serta berdoa juga sebab untuk mencegah bala petaka yang tidak di inginkan terjadi saat latihan. ${ }^{39}$

Berdoa yakni cara utama menyampaikan permohonan dan kerendahan hati bahwa ilmu yang kita punya bukan apa-apa dan tidak patut untuk disombongkan karena itu semua datangnya dari Allah. Dalam setiap kegiatan latihan kader dan anggota selalu di bina ilmu agama yang secara tidak langsung dirasakan oleh mereka. Dengan cara berdoa kepada Allah bukan hanya sekedar mengajukan permohonan dan permintaan akan tetapi menyerahkan segala perkara itu hanya kepada Allah. Bermunajat dan berdoa itu adalah adab kesopanan atau pun budi pekerti seorang kepada Allah SWT.40

\footnotetext{
37 Andri Hermawan, Wawancara, Pimpinan Yayasan Muda Berakblak, 07 Januari 2018

${ }^{38}$ Fadil, Wawancara, Anggota Perguruan Bela Diri Muda Berakblak, 07 Januari 2018

${ }^{39}$ Fauzi, Wawancara, Kader Perguruan Bela Diri Muda Berakblak, 07 Januari 2018

${ }^{40}$ Heru, Wawancara, Pelatih Perguruan Bela Diri Muda Berakblak, 07 Januari 2018
} 
74 |Jurnal Dakwah dan Komunikasi, Vol. 4 , No. 1 , 2019

\section{c. Hafalan Ayat Pendek dan Hadits Setiap Ujian Kenaikan Tingkat Sabuk Pengkaderan}

Dalam mengikuti ujian kenaikan tingkat sabuk seorang kader dan anggota perguruan dituntut untuk menghafal ayat Al-qur'an dan hadits sebagaimana wewenang Guru Besar, Dewan Pembina, Dewan Pelatih, dan peraturan Perguruan Bela Diri Muda Berakhlak. Perguruan Bela Diri Muda Berakhlak adalah sebuah Perguruan pencak silat yang menanamkan nilai-nilai keislaman bagi setiap kader dan anggotanya. Setiap kenaikan tingkat sabuk seorang kader dan anggota akan di uji jurus-jurus, gerakan, dan teknik-teknik lainnya yang bermanfaat bagi kesehatan tubuhnya. Sudah itu dewan guru memberikan hafalan ayat Alqur'an dan hadits kepada setiap kader dan anggota yang mengikuti ujian kenaikan sabuk perguruan tersebut. ${ }^{41}$ Seperti tingkat anak SD yang mulai dari sabuk kuning polos dan mengikuti ujian untuk kenaikan sabuk tingkat kuning strip I di anjurkan menghafal ayat 12, hadist pendek tentang bersabar dan ikhlas dan menghafal doa kegiatan sehari-hari. Juga tingkat anak SMP yang dari tingkat sabuk merah polos dan mengikuti ujian untuk kenaikan tingkat sabuk merah strip I, I, III dianjurkan menghafal ayat pilihan dari dewan guru seperti Al-Baqarah dan sebagainya. ${ }^{42}$

\section{d. Motivasi dan Binaan}

Kader dan anggota selalu di beri arahan baik motivasi yang bersifat Islami maupun binaan yang bersifat membangun, dalam hal ini dewan guru dan pembina memberikan motivasi atau nilai-nilai islamiyah kepada kader dan anggota sesudah kegiatan latihan berlangsung ataupun setiap latihan kalau anakanak dan remaja itu memerlukan siraman rohani. Perguruan Bela Diri Muda Berakhlak memiliki program kerja dalam membina kader dan anggotanya, kegiatan itu berlangsung sesudah latihan selesai, guru besar, dewan pembina, dan pelatih memberikan materi nilai-nilai keislaman yang terstruktur setiap bulannya. Waktu dalam menyampaikan materi guru besar, dewan pembina, dan pelatih mengisarkan 7-15 menit setelah kegiatan latihan selesai.

Saat latihan juga ketika anak-anak dan remaja itu memerlukan siraman rohani baik guru besar, dewan pembina, dan pelatih memberikan materi kepada kader dan anggota tersebut baik materi yang terstruktur maupun yang non terstruktur. Karena guru besar beranggapan bahwa anak-anak dan remaja sangat perlu didikan Islami dan binaan yang baik agar nantinya berguna baik bagi dirinya sendiri, keluarganya, maupun masyarakat dan bangsa Indonesia. ${ }^{43}$

\footnotetext{
${ }^{41}$ Hidayat, Wawancara, Kader Perguruan Bela Diri Muda Berakblak, 07 Januari 2018

42 Geri, Wawancara, Anggota Perguruan Bela Diri Muda Berakhlak, 07 Januari 2018

${ }^{43}$ Andri Hermawan, Wawancara, Pimpinan Yayasan Muda Berakblak, 05 Januari 2018
} 


\section{Nilai-Nilai Dakwah Dalam Yayasan Perguruan Bela Diri Muda Berakhlak}

\section{a. Nilai Kedisiplinan}

Nilai kedisiplinan sangat ditekankan dalam Perguruan Bela Diri Muda Berakhlak, Kader dan anggota di tuntut untuk taat dan patuh terhadap perguruan. Kader dan anggota perguruan selalu di didik dengan kedisiplinan dan selalu tepat waktu apabila kader dan anggota melanggar peraturan yang sudah di tetapkan dalam AD / ART akan dikenakan sanksi sesuai konsekuen yang berlaku, seperti kader dan murid datang telat setiap waktu latihan maka Guru besar atau dewan pelatih akan memberikan sanksi atau hukuman fisik seperti sit up, push up, merayap dan lari bolak-balik. Disiplin yang ditanamkan atas dasar kesadaran dapat menumbuhkan disiplin diri atau self discipline. Disini kader dan anggota apabila dikembangkan lebih lanjut akan menimbulkan pemahaman dan kesadaran yang lebih mendalam untuk mematuhi segala nilai-nilai, norma-norma, dan kaidah-kaidah yang berlaku. ${ }^{44}$

Nilai kedisiplinan adalah bagaimana cara kita mengatur waktu serta dapat digunakan sebaik-baiknya. Disini perguruan bela diri muda berakhlak menekankan kepada kader dan anggota perguruan agar selalu tepat waktu dalam mengikuti latihan, jika seorang telat datang saat latihan sudah dimulai maka dia akan menerima sanksi dari guru besar atau dewan pelatih. ${ }^{45}$

\section{b. Nilai Kejujuran}

Perguruan Bela Diri Muda Berakhlak selalu mendidik agar kader dan anggota perguruan selalu bersikap jujur dalam segala hal baik dalam latihan maupun dalam kehidupannya sehari-hari. Ketika seorang kader dan anggota salah dalam gerakan latihan atau menampilkan jurus-jurus yang telah di ajarkan maka dia harus jujur terhadap dirinya sendiri maupun kepada guru besar atau dewan pelatih dan menerima hukuman atau sanksi yang berlaku dalam perguruan sesuai dengan peraturan AD/ART. Bersifat jujur memang sulit ditanamkan dalam diri namun seiring berjalan waktu sifat itu akan bisa diterapkan dalam kepribadian masing-masing. ${ }^{46}$

\section{c. Nilai Kerja keras}

Dalam Perguruan Bela Diri Muda Berakhlak kader dan anggota selalu dibina dan dibimbing dengan nilai kerja keras, setiap kegiatan dan latihan itu tidak lah mudah sangat membutuhkan tenaga dan semangat yang tinggi, dalam hal ini kader dan anggota perguruan dibina agar berpegang teguh dengan pendirian harus bisa, seberat apapun kegiatan dan latihan itu jika dilakukan dengan sungguh-sungguh, niscaya hasilnya akan dapat diraih dengan baik. Kader

\footnotetext{
44 Andri Hermawan, Wawancara, Guru Besar Bela Diri Muda Berakblak, 05 Januari 2018

${ }^{45}$ Fauzi, Wawancara, Kader Perguruan Bela Diri Muda Berakblak, 05 Januari 2018

${ }^{46}$ Sabar, Wawancara, Ketua Perguruan Bela Diri Muda Berakblak, 05 Januari 2018
} 
dan anggota juga dituntut untuk selalu bersikap kreatif dan rajin dalam latihan dan belajar sebab tanpa usaha yang maksimal seseorang tidak akan dapat memenuhi kebutuhan dirinya. ${ }^{47}$

\section{d. Nilai Kebersihan}

Dalam hal ini kader dan anggota Perguruan Bela Diri Muda Berakhlak selalu dibina dan dituntut tentang arti pentingnya menjaga dan melestarikan lingkungan. Ketika suatu lingkungan bersih maka kesehatan kita akan terjaga, begitu sebaliknya ketika lingkungan tercemar dan kotor akan sangat mudah penyakit masuk ketubuh kita. Seperti halnya ketika sudah selesai latihan kita dianjurkan untuk membersihkan tubuh dari kotoran baik itu hanya sebatas cuci kaki atapun cuman mencuci tangan saja. ${ }^{48}$

\section{e. Nilai Kompetisi}

Kompetisi adalah keterampilan, pengetahuan, sikap dasar serta nilai yang dicerminkan kedalam kebiasaan berpikir dan bertindak yang sifatnya berkembang, dinamis, terus menerus serta dapat diraih setiap waktu. Jadi kompetisi adalah kemampuan yang ada pada diri seseorang untuk menunjukkan dan mengaplikasikannya tersebut di dalam kehidupan nyata.

Perguruan Bela Diri Muda Berakhlak selalu memberikan apresiasi kepada kader dan anggota yang berprestasi baik tingkat regional maupun tingkat nasional. Kader dan anggota yang mendapat medali atau penghargaan baik tingkat Kabupaten atau Provinsi akan menjadi motivasi kepada kader dan anggota yang lain agar selalu bersemangat untuk meraih cita-cita, impian dan prestasi.

Dalam hal ini, Perguruan Bela Diri Muda Berakhlak tidak mengharapkan setiap kader dan anggota selalu menang dalam setiap perlombaan dan turnamen melainkan menjadikan sebuah pengalaman dan pelajaran untuk kader dan anggota yang sudah ikut berpartisipasi dalam kegiatan tersebut. Karena, menang dan kalah itu adalah hal yang biasa dalam sebuah permainan melainkan untuk menjadikan pribadi kader dan anggota perguruan yang lebih berwawasan dan berpikir yang cerdas. ${ }^{49}$

\section{f. Nilai Solidaritas}

Perguruan Bela Diri Muda Berakhlak selalu menanamkan rasa solidaritas terhadap sesama baik kepada kader dan anggota seperguruan maupun kepada yang lain. Manfaat dari adanya rasa solidaritas ini akan ada rasa saling tolong menolong antara sesama dan adanya rasa peduli terhadap kawan. Dengan adanya rasa solidaritas ini dalam kehidupan sehari-hari maka akan terjalinnya tali

${ }^{47}$ Heru, Wawancara, Pelatih Perguruan Bela Diri Muda Berakblak, 05 Januari 2018

${ }^{48}$ Asep Abdullah, Wawancara, Anggota Perguruan Bela Diri Muda Berakblak, 07 Januari 2018

${ }^{49}$ Hidayat, Wawancara, Anggota Perguruan Bela Diri Muda Berakblak, 05 Januari 2018 
persaudaraan terhadap sesama, teman, ataupun keluarga. Jadi sudah seharusnya kita menumbuhkan rasa solidaritas dalam diri dan menjaganya agar tidak hilang dan tentunya kita dapat memanfaatkan dengan benar rasa solidaritas tersebut. ${ }^{50}$

\section{g. Nilai Tauhid}

Setiap kader anggota Bela Diri Muda Berakhlak selalu dibina dan ditanamkan nilai-nilai keislaman yakni keyakinan akan keesaan Allah SWT, seperti akan janji dasar dan inti dalam Perguruan Bela Diri Muda Berakhlak yaitu tidak menyekutukan Allah dan akan selalu berketuhanan yang maha esa. Dalam hal ini kader harus taat dan patuh dan taat kepada perguruan dan akan selalu mengamalkan nilai-nilai keislaman yang ditanamkan dalam Perguruan Bela Diri Muda Berakhlak. ${ }^{51}$

Sebelum masuk ke jenjang latihan kader perguruan bela diri muda berakhlak dibina dulu dan di luruskan niatnya ke jalan yang benar dan di ridhoi Allah supaya jika nanti sudah menjadi orang yang berilmu tidak akan sombong dan selalu mengagungkan nama Allah SWT dan akan selalu berkeyakinan teguh akan keesaan Allah SW'T. ${ }^{52}$

\section{h. Nilai Kesabaran}

Dalam Perguruan Bela Diri Muda Berakhlak seorang kader dan anggota dituntut untuk selalu bersabar dalam menjalani apapun baik kehidupan yang nyata maupun dalam kegiatan latihan. Seorang kader dan anggota perguruan akan tetap berdiri tegar dan mempunyai jiwa yang kuat dalam setiap kegiatan latihan dan itu harus mempunyai sifat yang sabar, karena sesuatu yang di awali dengan sabar apapun bentuk kegiatan itu akan terasa ringan. Setiap latihan itu tidak ada yang namanya mudah harus butuh perjuangan untuk mencapai level atau puncak pendekar, sebelum melewati tahap itu seorang murid atau kader yang baru bergabung tentu harus banyak ujian yang harus di lewati baik mental, fisik dan juga pemahaman ilmu agama. ${ }^{53}$

Dalam mengikuti setiap tahap-tahap atau level pengkaderan tentu itu tidak semudah yang dibayangkan, setiap kader dan anggota dalam Perguruan Bela Diri Muda Berakhlak tentu harus mengikuti latihan yang di programkan oleh perguruan baik ilmu agama, fisik, mental dan cara berpikir yang cerdas untuk menjatuhkan lawan, ketika seorang kader tersebut sudah bisa mengontrol emosi saja dalam latihan itu sudah bisa dikatakan rasa sabar nya sudah mulai tumbuh. Dalam mengikuti latihan banyak yang harus dilewati oleh setiap kader dan anggota perguruan baik itu medan yang mudah maupun medan yang sulit dan sangat membutuhkan fisik yang kuat. ${ }^{54}$

50 Ahmad Fauzi, Wawancara, Kader Perguruan Bela Diri Muda Berakblak, 05 Januari 2018

51 Andri Hermawan, Wawancara, Guru Besar Bela Diri Muda Berakblak, 05 Januari 2018

${ }^{52}$ Sabar, Wawancara, Pengurus Yayasan Perguruan Bela Diri Muda Berakblak, 05 Januari 2018

53 Ahmad Faizal, Wawancara, Pengurus Yayasan Perguruan Bela Diri Muda Berakblak, 05 Januari 2018

${ }^{54}$ Fauzi, Wawancara, Kader Perguruan Bela Diri Muda Berakblak, 05 Januari 2018 
78 |Jurnal Dakwah dan Komunikasi, Vol. 4 , No. 1, 2019

\section{i. Nilai Keikhlasan}

Dalam setiap mengikuti latihan seorang kader dan anggota perguruan di tuntut agar selalu menanamkan sifat yang ikhlas baik yang mengajarkan maupun yang menerima ilmu yang di sampaikan pelatih atau guru besar Bela Diri Muda Berakhlak, ketika seorang kader dan anggota perguruan sudah bisa ikhlas dalam mengikuti latihan apa yang di ajarkan dan di sampaikan itu akan mudah di amalkan.

Rasa ikhlas itu seiring dengan belajar dan latihan akan terasa dalam kehidupan sehari-hari, bukan hanya dalam Yayasan Perguruan Bela Diri Muda Berakhlak saja seorang kader dan anggota itu akan dituntut agar bisa menerapkan dalam lingkungan keluarganya ataupun dalam kehidupan bermasyarakat. Rasa ikhlas yaitu semata-mata mengharapkan ridha Allah SWT dengan tidak mengharapkan imbalan materi maupun non-materi berupa pujian, publikasi ataupun penghargaan duniawi lainnya yang ada di sekelilingnya. 55

\section{j. Nilai Istiqomah}

Setiap latihan kader dan anggota Perguruan Bela Diri Muda Berakhlak selalu di tuntut untuk selalu Istiqamah dengan kata lain berpegang teguh dan teguh pendirian. Ketika seorang kader dan anggota sudah bisa menerapkan berpegang teguh pada suatu titik kefokusan dalam latihan dan tetap berteguh pendirian harus bisa dalam medan ataupun tingkat level latihan serumit apapun itu harus bisa. Dalam Perguruan Bela Diri Muda Berakhlak seorang kader dan anggota tidak boleh mengeluh atapun menyerah sebelum bertanding, menang dan kalah itu biasa dalam sebuah permainan ataupun pertandingan. Didalam Perguruan Bela Diri Muda Berakhlak selalu di terapkan pantang kita mundur sebelum bertempur. ${ }^{56}$

\section{k. Akhlak}

Setiap kader dan anggota Perguruan Bela Diri Muda Berakhlak selalu ditumbuhkan dan ditanamkan Akhlak yang mulia dan sifat berperilaku terpuji sebagaimana lebel Perguruan Muda Berakhlak Mulia. Muda yang artinya Munculnya baru khusus membendung atau mendidik akhlak anak-anak dan remaja, dan Berakhlak Mulia artinya perilaku terpuji yang harus diterapkan dan dikembangkan oleh setiap kaderdan anggota perguruan dalam kehidupannya sehari-hari baik dalam keluarganya maupun dalam lingkungan masyarakat yang ada di sekitarnya. ${ }^{57}$

55 Subowo, Wawancara, Pengurus Yayasan Perguruan Bela Diri Muda Berakblak, 05 Januari 2018

56 Andri Hermawan, Wawancara, Guru Besar Bela Diri Muda Berakblak, Januari 2018

57 Anton HS, Wawancara, Kader Perguruan Bela Diri Muda Berakblak, 07 Januari 2018 
Bela Diri bukan hanya sebagai latihan cara bertanding, separing, ataupun menjatuhkan lawan di lapangan akan tetapi sebagai tameng untuk mengkokohkan diri dengan perilaku terpuji dan membantu orang yang lemah. Ketika seorang kader dan anggota perguruan memahami dan mengamalkan ilmu yang di dapat dalam latihan bukan hanya gerakan tendangan, pukulan, tangkisan, atapun teknik menjatuhkan lawan akan tetapi mengembangkan nilai-nilai islamiyah yang ada dalam perguruan bela diri muda berakhlak tersebut. Dalam perguruan bela diri muda berakhlak seorang kader dan anggota dituntut untuk selalu saling menolong dalam kebaikan, belajar bersama, gotong royong, dan selalu mengajak kepada kebaikan. ${ }^{58}$

Perubahan akhlak dan tingkah laku seorang anak bukan hanya belajar disekolah saja secara formal, melainkan ada pendidikan khusus non formal di sebuah organisasi keislaman dan ini sangat berguna bagi masyarakat itu sendiri khususnya untuk menitipkan anak mereka belajar di yayasan tersebut. Dalam latihan bela diri seolah tidak dirasakan oleh anak-anak bagimana seorang guru besar dan pelatih memberikan nilai-nilai keagamaan dalam latihan bela diri tersebut. Setelah seorang anak tergabung dalam Perguruan Bela Diri tersebut, dari sikap dan perilakunya sudah ada perubahan lebih baik dalam bergaul kepada teman sebayaknya dan sopan santunnya kepada orang tua. ${ }^{59}$

\section{Faktor pendukung dan penghambat dakwah Yayasan Perguruan Bela Diri Muda Berakhkak}

\section{a. Faktor Pendukung}

Yaitu dari pihak masyarakat seperti dalam bentuk bantuan secara material dan moral. Secara material yaitu berupa bantuan dana, sarana dan prasarana serta bantuan tenaga, sedangkan bantuan moral yaitu berupa kritik dan saran. Kemudian pihak lain yang mendukung kegiatan ini adalah Pemerintahan Daerah yaitu berupa dukungan dengan memberikan izin kepada Perguruan Bela Diri Muda Berakhlak guna kelancaran kegiatan dakwahnya. Serta kerja sama yang baik diantara kepengurusan, kader dan anggota Perguruan Bela Diri Muda Berakhlak sehingga pelaksanaan kegiatan dakwah dapat berjalan dengan baik. ${ }^{60}$

58 Bendra Wardana, Wawancara, Pembina/Pengawas Yayasan Perguruan Bela Diri Muda Berakblak, 07 Januari 2018 2018

${ }^{59}$ Rahma, Wawancara, Orang Tua Anggota Perguruan Bela Diri Muda Berakblak, 07 Januari

${ }^{60}$ Andri Hermawan, Wawancara, Guru Besar Bela Diri Muda Berakblak, 07 Januari 2018 


\section{b. Faktor Penghambat}

Dalam pelaksanaan kegiatan dakwah tersebut, Pihak pengurus Perguruan Bela Diri Muda Berakhlak mengalami beberapa kendala yang cukup menyulitkan untuk melaksanakan kegiatan dakwah. Kendala yang dimaksudkan dalam hal ini adalah kesulitan dalam mencari narasumber, guru atau pelatih yang dapat menjadi pemateri dalam kegiatan tersebut. Kemudian kendala yang di rasakan yaitu dalam hal kelengkapan sarana prasarana dikarenakan sarana yang dimiliki oleh Perguruan Bela Diri Muda Berakhlak ini masih dirasa kurang memadai. Selanjutnya lokasi yang sempit dan kurang memadai untuk kegiatan tersebut. Dan dalam segi dana menjadi penghambat yang sering dirasakan dalam hal pelaksanaan kegiatan, hal ini dikarenakan sulit memperoleh dana yang cukup dan sulit mendapatkan bantuan dana sehingga hanya mengandalkan dana dari kader, anggota dan masyarakat sekitar saja. ${ }^{61}$

\section{Penutup}

\section{Kesimpulan}

Dalam penelitian ini ada beberapa macam item atau point-poitn yang dapat disimpulkan diantaranya:

1. Aktivitas dakwah dalam yayasan bela diri muda berakhlak

Aktivitas dakwah yaitu kegiatan-kegiatan yang berkaitan dengan keagamaan, antara lain: berzikir, berdoa sebelum dan sesudah kegiatan latihan, hapalan ayat-ayat pendek dan hadits setiap ujian kenaikan tingkat sabuk dalam pengkaderan, serta motivasi dakwah dan binaan.

2. Nilai-nilai dakwah yang dikembangkan dan diterapkan dalam yayasan perguruan bela diri muda berakhlak

Setelah melakukan penelitian dan analisis, nilai-nilai dakwah tersebut antara lain: nilai kedisiplinan, nilai kejujuran, nilai kerja keras, nilai kebersihan, nilai kompetisi, nilai solidaritas, nilai tauhid, nilai kesabaran, nilai keikhlasan, nilai istiqomah dan akhlak terpuji.

3. Faktor pendukung dan penghambat dalam yayasan perguruan bela diri muda berakhlak

a. faktor pendukung yaitu; masyarakat dan pemerintah daerah

b. faktor penghambat diantaranya; kesulitan dalam mencari narasumber, guru, pelatih, dana, lokasi serta sarana dan prasarana.

${ }^{61}$ Sabar, Wawancara, Ketua Perguruan Bela Diri Muda Berakblak, 07 Januari 2018 


\section{Daftar Pustaka}

Alsa, Asmadi, Pendekatan Kuantitatif \& Kualitatif Serta Kombinasinya Dalam Penelitian Psikologi, (Yogyakarta: Pustaka Pelajar, 2011), Cet. Ke-V

Arikunto, Suharsimi Prosedur Penelitian, (Jakarta:Rineka Cipta, 2002)

Arikunto, Suharsimi, Prosedor Penelitian Suatu Pendekatan Praktis, (Jakarta:Rineka Cipta, 1998)

Azwar, Saifudin, Metode Penelitian,(Yogyakarta: Pustaka Pelajar, 2012)

Basit, Abdul, Filsafat Dakwah, (Jakarta: Direktorat Pendidikan Tinggi Islam Kementerian Agama RI, 2012)

Basit, Abdul, Filsafat Dakwah, (Jakarta: Rajawali Pers, 2013)

Bungin, Burhan, Analisis Data Penelitian Kualitatif, (Jakarta: Raja Grafindo Persada, 2006)

Bungin, Burhan, Metode Penelitian Kualitatif, Jakarta: Raja Grafindo Persada, 2006)

Bungin, Burhan, Metodologi Penelitian Kualitatif, (Jakarta: Rajawali Pers, 2010)

Departemen Agama RI, Al-Qur'an dan terjemahannya, (Semarang: Toha Putra, 1989)

Document, Perguruan Bela Diri Muda Berakblak, Tabun 2018

Herwantiyoko dan Neltje F. Katuuk, Pengantar Sosiologi dan Ilmu Dasar Sosial (Jakarta: Gunadarma, 1996), Edisi Pertama, Cet. Ke-I

Joko, Subagio, Metode Penelitian Dan Teori Dalam Praktek, (Jakarta: Rineka Cipta, 1991)

Komaruddin, Kamus Istilah Skripsi dan Tesis, (Angkasa, Bandung: 1985)

Munir, M. dan Wahyu Ilahi, Manajemen Dakwah (Jakarta: Kencana, 2009)

Nawawi, Hardadi dan M. Martini, Instrument Penelitan Bidang Sosial. (Yogyakarta: Gajah Mada Uniprisiti Prees, 1992)

Rahman, Abdul, Metode Dakwah, (Curup: LP2 STAIN Curup, 2010)

Sugiyono, Metode Penelitian KuntitatifKualitatif, R dan D, (Bandung: Alfabeta, 2014)

Sulthon, Muhamad, Desain Ilmu Dakwah, (Yogyakarta: Pustaka pelajar dan Walisongo Press, 2003)

Sulthon, Muhammad, Desain Ilmu Dakwah, (Yogyakarta: Pustaka Pelajar, 2003) 
82 |Jurnal Dakwah dan Komunikasi, Vol. 4 , No. 1 , 2019

Syarnubi, Sukarman, Metode Penelitian Kuantitatif dan Kualitatif, (Curup: LP2 STAIN Curup, 2011)

Yayasan, AD/ART, Perguruan Bela Diri Muda Berakhlak. 